\title{
Enhancement of a Landrace of Carosello (Unripe Melon) through the Use of Light-Emitting Diodes (LED) and Nutritional Characterization of the Fruit Placenta
}

\author{
Onofrio Davide Palmitessa ${ }^{1, *(\mathbb{D})}$, Miriana Durante ${ }^{2} \mathbb{D}$, Beniamino Leoni ${ }^{1}$, Francesco Montesano ${ }^{3} \mathbb{D}$, \\ Massimiliano Renna ${ }^{1,3}{ }^{(D)}$, Francesco Serio ${ }^{3}\left(\mathbb{D}\right.$, Annalisa Somma $^{1}$ and Pietro Santamaria ${ }^{1(D)}$ \\ 1 Department of Agricultural and Environmental Science, University of Bari Aldo Moro, via Amendola 165/a, \\ 70126 Bari, Italy; beniamino.leoni@uniba.it (B.L.); massimiliano.renna@uniba.it (M.R.); \\ annalisa.somma@uniba.it (A.S.); pietro.santamaria@uniba.it (P.S.) \\ 2 Institute of Sciences of Food Production, National Research Council of Italy, 73100 Lecce, Italy; \\ miriana.durante@ispa.cnr.it \\ 3 Institute of Sciences of Food Production, National Research Council of Italy, 70126 Bari, Italy; \\ francesco.montesano@ispa.cnr.it (F.M.); francesco.serio@ispa.cnr.it (F.S.) \\ * Correspondence: onofrio.palmitessa@uniba.it
}

\section{check for} updates

Citation: Palmitessa, O.D.; Durante, M.; Leoni, B.; Montesano, F.; Renna,

M.; Serio, F.; Somma, A.; Santamaria, P. Enhancement of a Landrace of Carosello (Unripe Melon) through the Use of Light-Emitting Diodes (LED) and Nutritional Characterization of the Fruit Placenta. Sustainability 2021, 13, 11464. https://doi.org/ 10.3390/ su132011464

Academic Editor: Primo Proietti

Received: 15 September 2021

Accepted: 14 October 2021

Published: 17 October 2021

Publisher's Note: MDPI stays neutral with regard to jurisdictional claims in published maps and institutional affiliations.

Copyright: (C) 2021 by the authors. Licensee MDPI, Basel, Switzerland. This article is an open access article distributed under the terms and conditions of the Creative Commons Attribution (CC BY) license (https:// creativecommons.org/licenses/by/ $4.0 /)$.
Abstract: Landraces of 'Carosello' (Cucumis melo L.) are a typical expression of Apulia's agrobiodiversity and are consumed in the same way as cucumbers. The aim of this research was to valorize the cultivation of a local variety of 'Carosello', extending the cultivation period and valorizing a part of the fruits that are generally wasted (endosperm). To accomplish this, a local variety called 'Carosello leccese' was grown in a greenhouse during the fall season under red + blue and red + blue + far red light-emitting diodes (LED) interlight. Yield, morphology, color and biochemical composition of the external and internal part of the fruit were evaluated. Although yield increased by $26 \%$ under supplemental light, the fruit quality was not influenced by LED application. However, the exocarp was greener (chlorophylls) and more yellow (carotenoids) than the mesocarp. Finally, the endosperm, which is the part of the fruit that is generally wasted, showed the highest polyphenols content, proving to be an important source of nutraceutical compounds. Therefore, it was demonstrated that the nutritional value of the endosperm is comparable or higher than the external part of the fruit, but further studies will be necessary to valorize it from a culinary perspective.

Keywords: landrace; Cucurbitaceae; fruit placenta; polyphenols; isoprenoids; agro-biodiversity; soilless

\section{Introduction}

The Cucurbitaceae family, one of the most important plant families, includes 118 genera and 825 species that provide humans with edible products and useful fibers [1]. Plants of this family are cultivated mostly for the production of fruits of different shapes and characteristics, which can be consumed ripe or immature, fresh or cooked. In addition sprouts [2], microgreens [3], flowers [4], seeds [5,6] and roots [7] can be used as edible parts, not forgetting that some Cucurbitaceae can be used to make tools such as containers, pipes and musical instruments [8]. Within the Cucurbitaceae family, the genus Cucumis L. consists of 32 species divided into two groups based on chromosomal number: Cucumis melo L. $(2 n=24)$ and C. satious L. $(2 n=14)$ [8].

The analyses of genetic structure, principal components and hierarchical clustering indicate that three clearly distinct subpopulations define the genetic variation of the C. melo L. germplasm cultivated in the Italian region of Apulia [9]. A genetic pool is represented by the local variety 'Carosello', referable to the chate taxonomic group [9]. This is one of the oldest domesticated forms of Cucumis melo L., once widespread in Europe and now exposed to the risk of genetic erosion [10]. Another subpopulation contains landraces of 'Barattiere', a regional vegetable production that was previously erroneously considered 
another form of chate melon [10]. The third subpopulation includes genotypes of winter melon (Cucumis melo L. var. inodorus) [10]. The genetic analysis within each subpopulation revealed patterns of diversity associated with fruit phenotype and geographical origin [9]. According to the study conducted by Perrino et al. [11], a large part of the immature melon population cultivated in the South of Italy, commonly called 'Carosello' and 'Barattiere', belong to C. melo L. subsp. melo conv. flexuosus. They are a part of a long history in Egypt [12]. From pharaonic times through the Roman Era, the very long cucumber-like melons, known as snake melons (C. melo L. subsp. melo conv. flexuosus), were more frequently illustrated and discussed than watermelons, implying that watermelons at that time did not possess all of the outstanding qualities of modern sweet watermelons [13]. In fact, Greek and Roman scripts dating back to the 1st century B.C. report that these people did not know the sweet melon, which was introduced into Europe only in the 13th century A.D. by travelers from Persia or the Caucasus [14]. Macchia and Pacucci [15] attributed to 'Carosello' the same chromosomal number $(2 n=24)$ of the melon and the landraces of 'Carosello' are considered interesting for agro-biodiversity protection, because they represent the trace of ancient Egyptian cultivars of which no specimens are available in the germplasm collections of Naudin, Pagalo and Grebenscikov [11]. Conversa et al. [8] found 18 local varieties of 'Carosello' in the Apulia region, which differ in the shape, color and size of the fruits. The high morphological variation of melon (in a broad sense) is mainly due to allogamy and to the fertility of its intraspecific crosses.

Carosello is a herbaceous plant [16] whose fruits are typically consumed at an immature stage, instead of cucumbers, due to their better quality profile [17]. Parente et al. [18] wrote that 'Carosello' fruits are characterized by being refreshing and digestible as well as having high potassium and low reducing sugar and sodium contents. The fruits of 'Carosello' are particularly appreciated by consumers due to the absence of bitter taste [8]. However, since they belong to the botanic family of Cucurbitaceae, the fruits of 'Carosello' could contain cucurbitacins, i.e., highly oxidized tetracyclic triterpenes with various bioactivities, such as anticancer, anti-inflammatory, and liver protection [19]. Cucurbitacin molecules uniquely arose in Cucurbitaceae to protect these plants from herbivorous insect species [20]. The harvest of 'Carosello' fruits is generally carried out when the fruits comprise a crunchy and consistent flesh texture, the seeds are still barely visible, and the placenta cavity is absent. Most consumers remove the placenta tissue from the fruits, because it is of a gelatinous consistency, but at this stage the whole placenta can also be consumed, and indeed some local people have named this part of the fruit "green caviar" [21]. 'Carosello' fruits can possess different shapes (from cylindrical to spherical), weight (from about 50 to over $300 \mathrm{~g}$ ) and rind colors (from light green to very dark green), and can present more or less dense pubescence [17]. There are currently no available statistical official data on the cultivation of 'Carosello', but it has been estimated to be approximately 1000 ha in Apulia (together with 'Barattiere'), mainly in the open field but also in greenhouse conditions [17] in one or two short cycles in a year. However, during the last years the cultivation area of the immature melons has been increased, expanding to other Italian regions such as Basilicata, Lazio, Campania, Sicily and Tuscany, and some international markets [21]. Moreover, the possibility of growing 'Carosello' plants in greenhouses allows for an extension of the harvesting period from early spring to late fall, while traditional cultivation in open fields makes fruit harvesting possible only during the summer period [18]. Finally, by growing 'Carosello' in greenhouses it is possible to reach a yield of 109-111 th.ha ${ }^{-1}$ [18].

During this research activity a local variety called 'Carosello leccese' (C. melo L. subsp. melo conv. flexuosus [11]) was cultivated in the greenhouse with a soilless system during the fall period. Following recent studies regarding the success of light-emitting diodes (LEDs) application as a supplementary light (SL) system in Mediterranean greenhouse conditions for tomato crops [22,23], we investigated the effects of this technology/technique on 'Carosello leccese' growth/yield, as a way to increase extra-seasonal fruit production. Finally, through the morphological and biochemical analysis of the fruits, the aim of this study 
was also to evaluate the main qualitative and nutritional characteristics of 'Carosello leccese', paying attention to the biochemical composition of the parts that make up the edible part of the fruits.

\section{Materials and Methods}

\subsection{Experimental Set-Up}

The research activity was carried out between September and November 2020 at the experimental farm "La Noria" of the Institute of Sciences of Food Production, National Research Council [Mola di Bari, Italy $\left(41.062156^{\circ} \mathrm{N}, 17.066914^{\circ} \mathrm{E}\right)$ ] in an unheated polymethacrylate greenhouse with a maximum height of $4.5 \mathrm{~m}$.

\subsection{Plant Material and Growing Conditions}

The landrace of Cucumis melo L. called 'Carosello leccese' was grown with a soilless system technique. The seedlings were grown until the second true leaf stage at the plant nursery (Liuzzi Plant, Fasano, BR-Italy) and transplanted in $10 \mathrm{~L}$ pot filled with a mixture composed by peat (Brill 3 Special, Brill Substrate GmbH \& Co., Georgsdorf, Germany) and perlite (Agrilit 3, Perlite Italiana, Corsico-Milano, Italy) in a 1:1 $(v / v)$ ratio. Ten pots were placed on each aluminum trough bench (length $3 \mathrm{~m}$, width $0.26 \mathrm{~m}$, slope $1 \%$, distance between benches $1.2 \mathrm{~m}$ ). Plants distance on the bench was $0.30 \mathrm{~cm}$ with a stem density of 2.78 plants $\mathrm{m}^{-2}$. The experimental layout consisted of eleven trough benches (nine benches for the experimental units, and two benches as external guard rows which also included the first and last plant in each row). The principal stem of each plant was trained vertically and the lateral stems were topped after the second node. Periodically, the oldest leaves were removed. The greenhouse temperature was controlled by natural ventilation through ridge openings, set to open automatically above $20^{\circ} \mathrm{C}$. Pollination was guaranteed by introduction of bumblebees (Bombus terrestris L.) into the greenhouse. Temperature and relative humidity were recorded by a CR1000 datalogger (Campbell Scientific, Logan, UT, USA).

\subsection{Nutrient Solution (NS) Management}

The nutrient solution (NS) was supplied with the micro-irrigation technique in a close cycle. For each pot a self-compensating drip (Netafim, Tel Aviv, Israel) was installed, which supplied NS with a flow rate of $4 \mathrm{~L} \cdot \mathrm{h}^{-1}$.

A $100 \mathrm{~L}$ tank containing NS was situated at the lower end of each trough bench. The NS was re-circulated according to closed-cycle management and was never discharged during the growing cycle. The fertigation schedule was set to avoid water stress, so the number of irrigation events was adjusted during the growing cycle, depending on environmental conditions and plant stage. Three times per week the tank was topped up with fresh NS and the amount added was used to calculate plant consumption of NS. The $\mathrm{pH}$ and electrical conductivity (EC) were measured before and after each addition of NS to the tank. During the crop cycle, three NS with increasing values of Silicon (Table 1) were supplied to reduce the incidence of powdery mildew and to increase overall fruit quality [16]. Micronutrients composition was kept constant during the growing cycle according to Hoagland and Arnon [24].

Table 1. Nutrient solutions (NS) composition during the crop cycle, expressed as $\mathrm{mg} \cdot \mathrm{L}^{-1}$.

\begin{tabular}{cccccccc}
\hline & $\mathbf{N}$ & $\mathbf{K}$ & $\mathbf{P}$ & $\mathbf{M g}$ & $\mathbf{C a}$ & $\mathbf{S i}$ & $\mathbf{S}$ \\
\hline Days after transplant (DAT) & & & & $\mathrm{mg} \cdot \mathrm{L}^{-1}$ & & & \\
\hline $1-31$ & 145 & 208 & 40 & 23 & 133 & 20 & 82 \\
$32-40$ & 145 & 239 & 40 & 23 & 133 & 60 & 82 \\
$41-81$ & 145 & 270 & 40 & 23 & 133 & 100 & 82 \\
\hline
\end{tabular}




\subsection{Supplementary Light Treatments}

Supplementary light (SL) was provided by light-emitting diodes (LED) interlight fixtures ("GreenHouse Interlight" produced by C-Led, Imola (BO), Italy). Each module carried two series of LEDs with $120^{\circ}$ luminous flux angle. Supplementary photosynthetic photon flux density (PPFD) was $170 \mu \mathrm{mol} \cdot \mathrm{m}^{-2} \cdot \mathrm{s}^{-1}$ at $30 \mathrm{~cm}$ from the lamp. Two light spectra were tested: Red $(660 \mathrm{~nm})+$ Blue $(440 \mathrm{~nm})(\mathrm{R}+\mathrm{B})$ and Red + Blue + Far Red $(730 \mathrm{~nm})(\mathrm{R}+\mathrm{B}+\mathrm{FR})$. The light spectrum ratios were: 4 (Red): 1 (blue) for $\mathrm{R}+\mathrm{B}$ and 4 (red): 1 (Blue): 1 (Far Red) for R + B + FR. Natural light (NL, no supplementary lighting, three benches) was used as control. The interlight modules were placed $25 \mathrm{~cm}$ below the apical meristem and the height of the LEDs was adjusted once a week to maintain a constant distance between the apical meristem and the fixtures, to ensure uniform light distribution and intensity. The light treatments started at transplant date with the LED modules above the apical meristems (the plants were $15 \mathrm{~cm}$ tall) and continued until the end of the crop cycle. The SL was operated automatically by a system composed of a CR1000 datalogger (Campbell Scientific, Logan, UT, USA) and a quantum sensor (LI-190R, LI-COR, Lincoln, $\mathrm{NE}, \mathrm{USA}$ ). For $16 \mathrm{~h} \cdot \mathrm{d}^{-1}$ (from 5:00 to 21:00), the system measured incoming sunlight in the greenhouse on a four-second basis and turned on the LED light bars whenever the ambient PPFD dropped below $200 \mu \mathrm{mol} \cdot \mathrm{m}^{-2} \cdot \mathrm{s}^{-1}$. The bars remained on until sunlight PPFD rose again above this set-point.

\subsection{Yield, Fruit Fresh and Dry Weight, and Biometric Characteristics}

Starting from 25 DAT the fruits were harvested twice a week when the grooves on the epicarp of the fruits were barely noticeable (Figure 1). After the harvesting operation, the biometric characteristics of the fruits were measured: fresh and dry weight (DW), fruit length (Figure 2a), equatorial diameter (Figure 2b), polar diameter (Figure 2c), endosperm length and width (Figure 2d) and mesocarp thickness (Figure 2e). For the measurement of DW, fresh samples (half part of each fruit) were kept in a forced draft oven at $105^{\circ} \mathrm{C}$ until constant weight was reached.

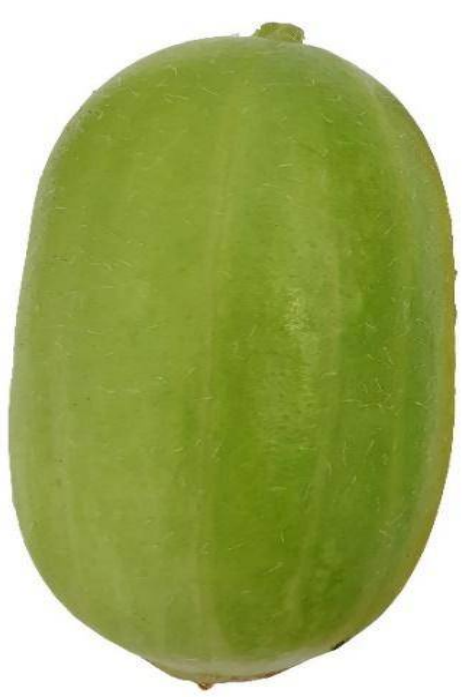

Figure 1. 'Carosello leccese' at harvest time with the grooves on the epicarp barely noticeable. 

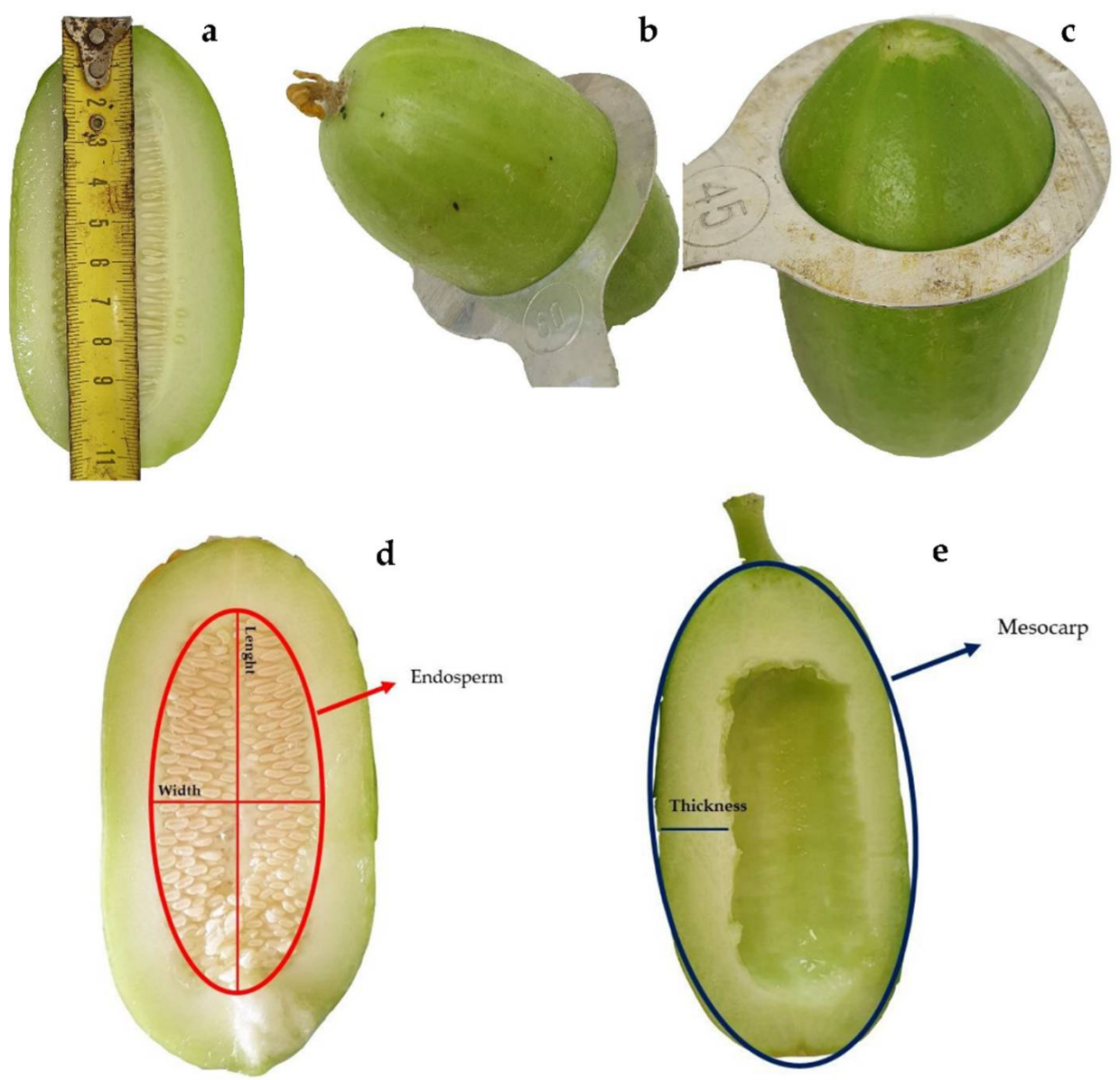

Figure 2. Biometric analysis carried out on the harvested fruits: (a) fruit length, (b) equatorial diameter, (c) polar diameter, (d) endosperm length and width, (e) mesocarp thickness.

\subsection{Color Analysis}

'Carosello leccese' fruits were cut longitudinally and the colors of their external and internal surfaces were measured by using the CIELAB scale $\left(\mathrm{L}, \mathrm{a}^{*}, \mathrm{~b}^{*}\right)$ with a portable tristimulus color-meter (Minolta Chroma Meter CR-400; Minolta Camera Co. Ltd., Osaka, Japan), according to the procedure described by Renna et al. [25]. The instrument runs with the color-space coordinates designed as: L, "lightness" (ranging from black $=0$ to white $=100$ ); $a^{*}$, "red/green chromaticity"; $b^{*}$, "yellow/blue chromaticity". Through trigonometric functions, other color indices were calculated: (i) color saturation, $C=\left[\left(\mathrm{a}^{*}\right)^{2}+\left(\mathrm{b}^{*}\right)^{2}\right]^{1 / 2}$; (ii) hue angle, $\mathrm{h}^{\circ}=\tan ^{-1}\left(\mathrm{~b}^{*} / \mathrm{a}^{*}\right)$. Before the measurements, the colorimeter was calibrated with a standard reference with $\mathrm{L}, \mathrm{a}^{*}$, and $\mathrm{b}^{*}$ values of $97.01,0.10$, and 1.88 , respectively.

\subsection{Polyphenols Determination}

For each light treatment and replication, a sample of 'Carosello leccese' fruits harvested on 32 and 50 DAT was used for chemical analysis, while on 50 DAT only for the fruits of control light treatment (Natural light) the endosperm was separated from the rest of the fruits and the two parts obtained were analyzed separately. To prepare the samples for the chemical analysis, about $120 \mathrm{~g}$ of fruits were freeze-dried until reaching stable weight by a freeze dry system (model LABCONCO FreeZone ${ }^{\circledR} 7,754,030$-Kansas City, MI, USA) equipped with a stoppering tray dryer (model LABCONCO FreeZone ${ }^{\circledR} 7,948,030$ Kansas City, MI, USA). The freeze-dried samples were ground at $500 \mu \mathrm{m}$ by using a Retsch laboratory mill (Torre Boldone, BG, Italy) to obtain a homogeneous powder.

Polyphenols were extracted with the methodology of Abu-Reidah et al. [26] and barely modified. Two $\mathrm{mL}$ of methanol $80 \%$ (v:v) were added to $100 \mathrm{mg}$ of lyophilized samples. They were vortexed (1 $\mathrm{min}, 3000 \mathrm{rpm})$, sonicated for $30 \mathrm{~min}$ in a Labsonic177 LBS1-10 
ultrasonic bath (Falc Instruments, Treviglio, Italy) and shaken with a magnetic stirrer for $5 \mathrm{~h}$. The samples were centrifuged at $4500 \times \mathrm{g} 10 \mathrm{~min}$ and the supernatant was dried through an evaporator at $40{ }^{\circ} \mathrm{C}$, solubilized with $100 \mu \mathrm{L}$ of methanol $80 \%$ (v:v), filtered with filters of $0.2 \mu \mathrm{m}$ and analyzed with HPLC as reported by Laddomada et al. [27]. Phenolic compound separation was achieved using a Phenomenex-luna 5 um C18 (2) $100 \AA$ column $(250 \times 4.6 \mathrm{~mm})$ (Phenomenex, Torrance, CA, USA). A gradient elution program was utilized with a mobile phase consisting of acetonitrile (solution A) and $1 \%(v / v) \mathrm{H}_{3} \mathrm{PO}_{4}$ in water (solution $\mathrm{B}$ ) as follows: isocratic elution, $100 \% \mathrm{~B}, 0-30 \mathrm{~min}$; linear gradient from $100 \%$ B to $85 \%$ B, 30-55 min; linear gradient from $85 \%$ B to $50 \%$ B, 55-80 min; linear gradient from $50 \%$ B to $30 \%$ B, $80-82$ min; post time, 10 min before the next injection. The flow rate of the mobile phase was $1.0 \mathrm{~mL} / \mathrm{min}$, the injection volume was $20 \mu \mathrm{L}$ and the temperature of the column was set at $30^{\circ} \mathrm{C}$. Wavelengths used for quantification of phenolic compounds were 280, 295, 320 and $350 \mathrm{~nm}$. Calibration standards were prepared in the range of $5 \mu \mathrm{g} / \mathrm{mL}$ to $500 \mu \mathrm{g} / \mathrm{mL}$ using eight concentration levels.

All of the calibration curves showed good linearity in the analyzed range 5-500 $\mu \mathrm{g} / \mathrm{mL}$ using eight concentration levels, with $\mathrm{R}^{2}$ values ranging from 0.9852 to 1 . LOD and LOQ values were found in the range $0.22-0.48$ and $0.78-1.46 \mu \mathrm{g} / \mathrm{mL}$, respectively.

\subsection{Isoprenoids Determination}

Triplicate aliquots of freeze-dried 'Carosello leccese' fruits powder (500 mg) were resuspended in $5 \mathrm{~mL}$ of distilled water, thus obtaining a homogeneous suspension. Isoprenoids (tocopherols, carotenoids, and chlorophylls) extraction was performed on $500 \mathrm{mg}$ of the homogeneous suspension through the method of Sadler et al. [28] as modified by Perkins-Veazie et al. [29]. Isoprenoid analyses were carried out by HPLC as described by Durante et al. [30] using an Agilent 1100 Series HPLC system equipped with a reversephase C30 column $(5 \mu \mathrm{m}, 250 \times 4.6 \mathrm{~mm})$ (YMC Inc., Wilmington, NC, USA). The mobile phases were: methanol (A), $0.2 \%$ ammonium acetate aqueous solution/methanol (20/80, $v / v)(B)$ and tert-methyl butyl ether (C). The gradient elution was as follows: $0 \mathrm{~min}, 95 \% \mathrm{~A}$ and $5 \% \mathrm{~B} ; 0-12 \mathrm{~min}, 80 \% \mathrm{~A}, 5 \% \mathrm{~B}$ and $15 \% \mathrm{C} ; 12-42 \mathrm{~min}, 30 \% \mathrm{~A}, 5 \% \mathrm{~B}$ and $65 \% \mathrm{C} ; 42-60 \mathrm{~min}$, $30 \% \mathrm{~A}, 5 \% \mathrm{~B}$ and $65 \% \mathrm{C} ; 60-62 \mathrm{~min}, 95 \% \mathrm{~A}$, and $5 \% \mathrm{~B}$. The column was re-equilibrated for $10 \mathrm{~min}$ between runs. The flow rate was $1.0 \mathrm{~mL} / \mathrm{min}$ and the column temperature was maintained at $25{ }^{\circ} \mathrm{C}$. The injection volume was $10 \mu \mathrm{L}$. The detector was set at $290 \mathrm{~nm}$, $350 \mathrm{~nm}$ and $665 \mathrm{~nm}$ for total tocopherols, carotenoids, and chlorophylls, respectively. All of the calibration curves showed good linearity in the analyzed range $5-500 \mu \mathrm{g} / \mathrm{mL}$ for tocopherols, $0.1-20 \mu \mathrm{g} / \mathrm{mL}$ for carotenoids and $4-50 \mu \mathrm{g} / \mathrm{mL}$ for chlorophylls, with $\mathrm{R}^{2}$ values ranging from 0.9982 to 1 .

The detector was set at $290 \mathrm{~nm}, 350 \mathrm{~nm}$ and $665 \mathrm{~nm}$ for total tocopherols, carotenoids, and chlorophylls, respectively.

\subsection{Chemicals}

Tocopherols and polyphenols standards, as well as all HPLC grade solvents were purchased from Sigma-Aldrich (Milan, Italy). Carotenoids standards were purchased from Cayman chemicals (Ann Arbor, MI, USA). Chlorophylls in acetone were purchased from DHI Water \& Environment (Copenhagen, Denmark).

\subsection{Experimental Design and Statistical Analysis}

The supplementary light treatments were arranged in a randomized block design with three replications. All data underwent analysis of variance (ANOVA) using the General Linear model (GLM; SAS Software, Cary, NC, USA). The experimental factors were fixed by one-way analysis of variance (ANOVA) and the orthogonal contrasts technique was used to establish differences between means (two contrasts): (1) NL vs. LED; (2) R + B vs. $\mathrm{R}+\mathrm{B}+\mathrm{FR}$. 


\section{Results}

\subsection{PPFD, DLI and Photoperiod}

During the fall season, the natural light intensity (PPFD max) decreased day by day along with the photoperiod (Figure 3). As shown in Figure 3, the maximum PPFD supplied from natural light (NL) from 1 to 4 DAT exceeded $700 \mu \mathrm{mol} \cdot \mathrm{m}^{-2} \cdot \mathrm{s}^{-1}$ and these values were no longer reached during the crop cycle. In fact, if during the middle stage of the crop cycle (from 30 to 60 DAT) the maximum PPFD $\left(523 \mu \mathrm{mol} \cdot \mathrm{m}^{-2} \cdot \mathrm{s}^{-1}\right)$ was reached on $46 \mathrm{DAT}$, on the last days of cultivation (from $61 \mathrm{DAT}$ to the end of the crop cycle) the highest PPFD value was reached on 64 DAT $\left(413 \mu \mathrm{mol} \cdot \mathrm{m}^{-2} \cdot \mathrm{s}^{-1}\right.$; Figure 3$)$. Considering the natural photoperiod, it was almost $14 \mathrm{~h}$ on the transplant date and it decreased almost linearly during the season, down to $9.5 \mathrm{~h}$ recorded on the last day of cultivation (81 DAT; Figure 3). Obviously, the trend of the natural daily light integral (DLI NL) was strictly connected with the light intensity and photoperiod; in fact, as PPFD max and photoperiod, it decreased during the crop cycle (Figure 3). The highest DLI NL value was $13.6 \mathrm{~mol} \cdot \mathrm{m}^{-2}$ and it was recorded on 2 and 3 DAT (Figure 3), while the lowest values were found on 71 and 75 DAT $\left(<1 \mathrm{~mol} \cdot \mathrm{m}^{-2} \cdot \mathrm{d}^{-1}\right.$; Figure 3$)$. On average, during the whole crop cycle, the plants received $7.33 \mathrm{~mol} \cdot \mathrm{m}^{-2} \cdot \mathrm{d}^{-1}$ from the sun radiation (Figure 3). During this experiment, we did not use a dimmable LED module so the PPFD emitted from SL was kept constant. Unlike what has been observed for NL, the daily light integral supplied from LED modules (DLI SL) increased during the crop cycle (Figure 3). The lowest DLI SL values (around $5 \mathrm{~mol} \cdot \mathrm{m}^{-2} \cdot \mathrm{d}^{-1}$ ) were obtained at the beginning of the crop cycle, while the highest DLI SL values (around 9-10 $\mathrm{mol} \cdot \mathrm{m}^{-2} \cdot \mathrm{d}^{-1}$ ) were observed at the end of the cultivation (Figure 3). On average, during the whole crop cycle, LEDs supplied $7.0 \mathrm{~mol} \cdot \mathrm{m}^{-2} \cdot \mathrm{d}^{-1}$ (Figure 3).

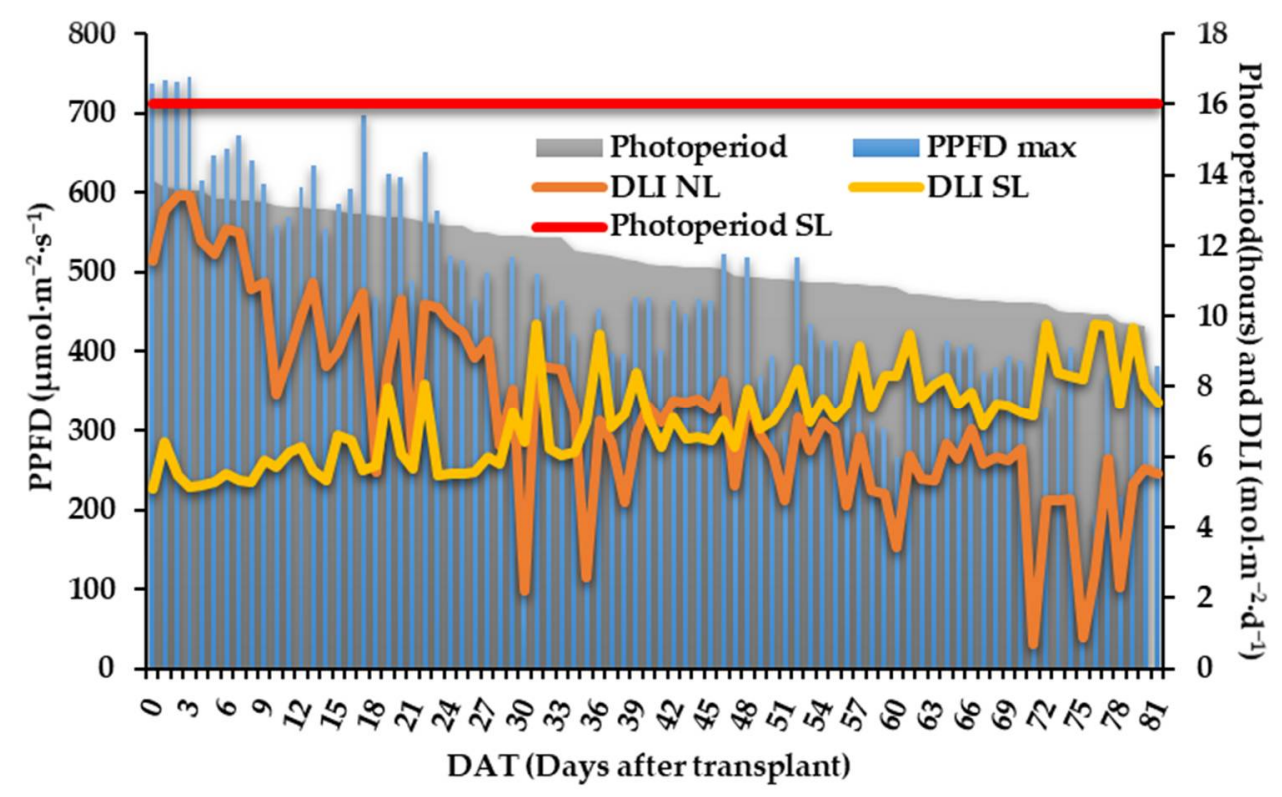

Figure 3. Natural light photoperiod (Photoperiod NL), maximum daily photosynthetic photon flux density supplied from natural light (PPFD max), daily light integral supplied from natural light (DLI NL), daily light integral supplied from LEDs (DLI SL) and photoperiod for the plants grown under LEDs (Photoperiod SL) during the crop cycle.

\section{2. 'Carosello leccese' Yield and Fruit Morphology}

The first fruits were harvested on 28 DAT (Figure 4). The plants of 'Carosello leccese' grown under LEDs increased the total yield by $27 \%$ compared with the plants grown only with natural light (NL; Table 2). Until 43 DAT no significant differences in yield were found between the plants grown under LEDs and those grown with only NL; the difference became significant from 45 DAT to the end of the crop cycle (Figure 4). Moreover, considering the number of fruits harvested, the plants of 'Carosello leccese' grown under 
LEDs showed more fruits (26\%) than under NL (Table 2). Average fruit weight and fruit dry weight were $218.7 \mathrm{~g}$ and $4.2 \mathrm{~g} \cdot 100 \mathrm{~g}^{-1} \mathrm{FW}$, respectively, regardless of the light treatments (Table 2).

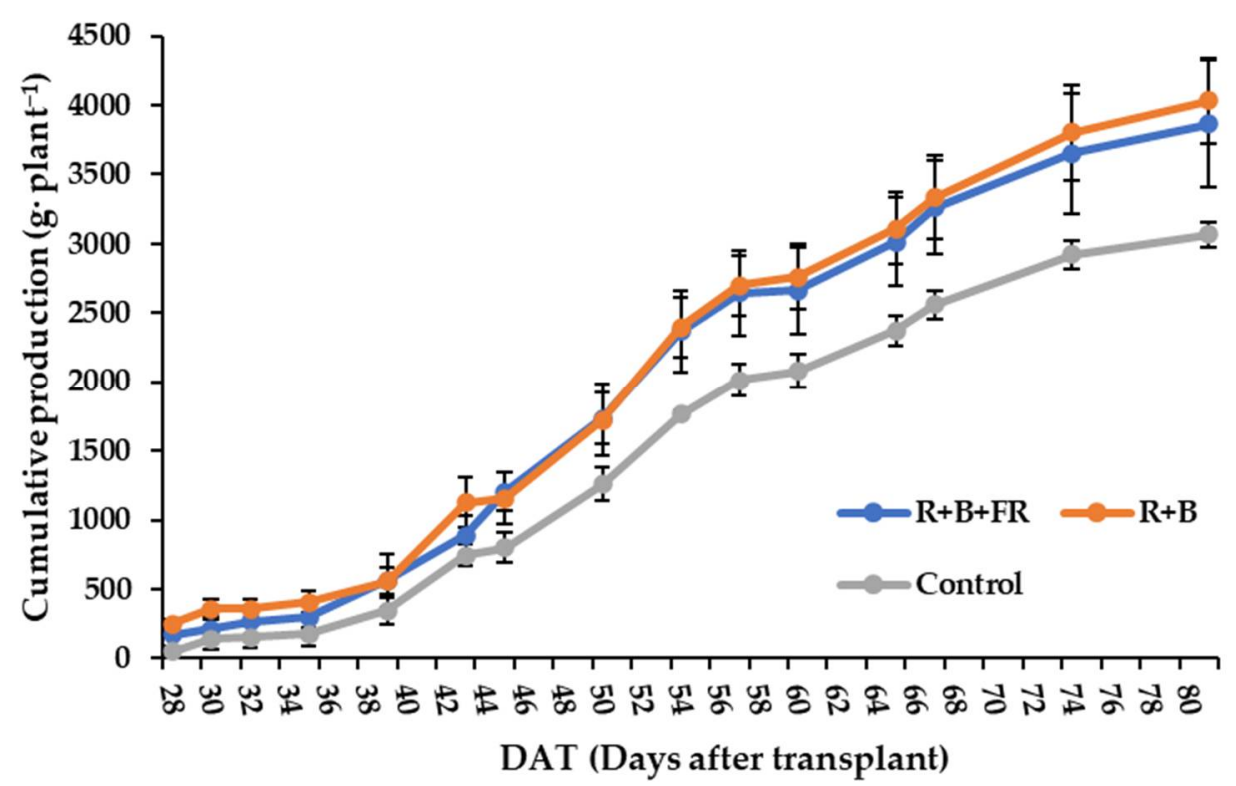

Figure 4. Cumulative production by plants grown under natural light (control) and supplemental light spectra (Red + Blue + Far Red: R + B + FR; Red + Blue: R + B) conditions. Values are an average of three replications. Vertical bars represent \pm standard error of mean values.

Table 2. Effects of light treatments on total number of fruits, total yield, average fruit weight and fruit dry weight of 'Carosello leccese'. Values are an average of three replications.

\begin{tabular}{|c|c|c|c|c|}
\hline & $\begin{array}{c}\text { Number of } \\
\text { Fruits }\end{array}$ & Yield & $\begin{array}{l}\text { Average Fruit } \\
\text { Weight }\end{array}$ & $\begin{array}{c}\text { Fruit Dry } \\
\text { Weight }\end{array}$ \\
\hline $\begin{array}{l}\text { Light } \\
\text { treatments }\end{array}$ & $\mathrm{n} \cdot$ plant $^{-1}$ & g.plant ${ }^{-1}$ & $\mathrm{~g} \cdot$ fruit $^{-1}$ & $\mathrm{~g} \cdot 100 \mathrm{~g}^{-1}$ fresh weight \\
\hline Natural light (NL) & $13.7 \pm 1.2$ & $3021 \pm 96$ & $221.0 \pm 12.3$ & $4.1 \pm 0.31$ \\
\hline $\mathrm{LED} \mathrm{R}+\mathrm{B}+\mathrm{FR}$ & $17.5 \pm 1.7$ & $3647 \pm 558$ & $207.7 \pm 13.6$ & $4.5 \pm 0.33$ \\
\hline LED R + B & $17.0 \pm 2.2$ & $4041 \pm 223$ & $227.3 \pm 14.3$ & $3.9 \pm 0.31$ \\
\hline \multicolumn{5}{|l|}{ Significance $^{(1)}$} \\
\hline NL vs. LEDs & $*$ & $*$ & ns & ns \\
\hline $\mathrm{R}+\mathrm{B}+\mathrm{FR}$ vs. $\mathrm{R}+\mathrm{B}$ & ns & ns & ns & ns \\
\hline
\end{tabular}

(1) Significance: ${ }^{*}=p \leq 0.05 ; \mathrm{ns}=$ not significant.

The morphological characteristics of 'Carosello leccese' fruits did not vary among the treatments (Table 3). Considering the fruits harvested from 39 to 71 DAT, the average equatorial diameter, polar diameter, mesocarp thickness, fruit length, endosperm width and endosperm length were, respectively: $62.0 \mathrm{~mm}, 45.0 \mathrm{~mm}, 14.8 \mathrm{~mm}, 116.7 \mathrm{~mm}, 28.7 \mathrm{~mm}$, and $85.0 \mathrm{~mm}$ (Table 3). 
Table 3. Effects of different light treatments on 'Carosello leccese' fruit morphology. Values are an average of fruit harvested on $39,43,50,53,56,63,65$, and $71 \mathrm{DAT} \pm \mathrm{SD}$ of three replications made during the growing cycle.

\begin{tabular}{|c|c|c|c|c|c|c|}
\hline & $\begin{array}{c}\text { Equatorial } \\
\text { Diameter }\end{array}$ & $\begin{array}{c}\text { Polar } \\
\text { Diameter }\end{array}$ & $\begin{array}{l}\text { Mesocarp } \\
\text { Thickness }\end{array}$ & Fruit Length & $\begin{array}{l}\text { Endosperm } \\
\text { Width }\end{array}$ & $\begin{array}{l}\text { Endosperm } \\
\text { Length }\end{array}$ \\
\hline $\begin{array}{l}\text { Light } \\
\text { treatments }\end{array}$ & \multicolumn{6}{|c|}{$\mathrm{mm}$} \\
\hline Natural light (NL) & $61.5 \pm 17.7$ & $44.8 \pm 11.6$ & $14.9 \pm 3.4$ & $117.3 \pm 19.8$ & $29.4 \pm 5.6$ & $86.5 \pm 16.4$ \\
\hline LED R + B + FR & $61.6 \pm 16.9$ & $43.8 \pm 12.4$ & $14.4 \pm 3.3$ & $116.6 \pm 19.5$ & $29.0 \pm 6.1$ & $85.1 \pm 16.5$ \\
\hline LED R + B & $62.8 \pm 17.1$ & $46.5 \pm 12.2$ & $15.1 \pm 2.9$ & $116.3 \pm 20.4$ & $27.7 \pm 6.0$ & $83.4 \pm 15.9$ \\
\hline Significance ${ }^{(1)}$ & & & & & & \\
\hline Control vs. LEDs & ns & ns & ns & ns & ns & ns \\
\hline$R+B+F R$ vs. $R+B$ & ns & ns & ns & ns & ns & ns \\
\hline
\end{tabular}

(1) Significance: $\mathrm{ns}=$ not significant.

\subsection{Color Traits}

The lightness $\left(\mathrm{L}^{*}\right)$ of the 'Carosello leccese' fruits was almost $22 \%$ higher for the internal tissue (mesocarp) than the external one (Table 4), while it did not vary among the light treatments (Table 4 ). At the same time, the $\mathrm{a}^{*}$ value of the exocarp was almost $72 \%$ lower than the mesocarp and its average value was -14.5 (Table 4 ). By contrast, the $b^{*}$ value was $46 \%$ higher for the exocarp tissue than the mesocarp tissue of 'Carosello leccese' fruits (Table 4). Considering the parameter $\mathrm{h}^{\circ}$, it was almost $3 \%$ higher on the skin of the fruits (exocarp) than the mesocarp (Table 4). Finally, the parameter C (Chroma) was almost $51 \%$ higher on the exocarp, compared to the mesocarp (Table 4).

Table 4. Analysis of color parameters of 'Carosello leccese' exocarp and mesocarp harvested on 50 DAT and effects of light treatments. Values are an average of three replications.

\begin{tabular}{|c|c|c|c|c|c|}
\hline & $\mathbf{L}^{*}$ & $a^{*}$ & $\mathbf{b}^{*}$ & HUE & C \\
\hline & $(0-100)$ & $(-60 /+60)$ & $(-60 /+60)$ & $\sqrt{ }\left(a^{2}+b^{2}\right)$ & $(0-360)^{\circ}$ \\
\hline $\begin{array}{l}\text { Fruit part } \\
\text { Exocarp }\end{array}$ & $67.3 \pm 3.3$ & $-18.4 \pm 1.4$ & $34.9 \pm 2.2$ & $117.8 \pm 1.1$ & $39.4 \pm 1.3$ \\
\hline $\begin{array}{l}\text { Mesocarp } \\
\text { Light treatment (SL) }\end{array}$ & $82.0 \pm 1.4$ & $-10.7 \pm 0.6$ & $23.9 \pm 1.9$ & $114.1 \pm 1.0$ & $26.1 \pm 1.8$ \\
\hline Natural light & $73.9 \pm 1.8$ & $-14.2 \pm 1.1$ & $28.6 \pm 2.0$ & $116.0 \pm 1.2$ & $32.0 \pm 2.3$ \\
\hline $\mathrm{R}+\mathrm{B}+\mathrm{FR}$ & $75.1 \pm 2.4$ & $-14.8 \pm 0.7$ & $29.7 \pm 1.4$ & $116.1 \pm 1.2$ & $33.2 \pm 1.2$ \\
\hline $\begin{array}{l}\mathrm{R}+\mathrm{B} \\
\text { Significance } \\
\end{array}$ & $75.0 \pm 2.1$ & $-14.6 \pm 1.4$ & $29.8 \pm 1.4$ & $115.7 \pm 0.9$ & $33.2 \pm 1.8$ \\
\hline Fruit part & $* *$ & $* * *$ & $* * *$ & $* *$ & $* * *$ \\
\hline SL & ns & ns & ns & ns & ns \\
\hline Fruit part $\times$ SL & ns & ns & ns & ns & ns \\
\hline
\end{tabular}

(1) Significance: $\mathrm{ns}=$ not significant; ** and ${ }^{* * *}$ significant for $p \leq 0.01$ and $p \leq 0.001$, respectively.

\subsection{Biochemical Characterization of 'Carosello leccese' Fruits Grown under Different Supplementary Light Conditions}

The content of polyphenols, carotenoids and chlorophylls did not vary between the different harvest periods and SL conditions (Table 5). On average, the contents of polyphenols, carotenoids and chlorophylls for "Carosello leccese" fruits were 3.76, 3.52 and $3.58 \mu \mathrm{g} \cdot \mathrm{g}^{-1}$ at fresh weight, respectively (Table 5). By contrast, the tocopherols content was $55 \%$ higher on 50 DAT compared with the fruits harvested on 32 DAT (Table 5). The average tocopherols content in "Carosello leccese" fruits were $0.62 \mu \mathrm{g} \cdot \mathrm{g}^{-1}$ fresh weight (Table 5). 
Table 5. Total polyphenols, tocopherols, carotenoids and chlorophylls contents of the overall fruit of 'Carosello leccese' harvested on 32 and 50 DAT under "Natural light", R + B + FR and R + B supplementary light treatments. Values are an average \pm SD of three replications.

\begin{tabular}{|c|c|c|c|c|}
\hline & Polyphenols & Tocopherols & Carotenoids & Chlorophylls \\
\hline & \multicolumn{4}{|c|}{$\mu \mathrm{g} \cdot \mathrm{g}^{-1}$ fresh weight } \\
\hline $\begin{array}{l}\text { Day of harvest (DAT) } \\
32\end{array}$ & $3.35 \pm 0.39$ & $0.49 \pm 0.10$ & $2.92 \pm 1.09$ & $2.64 \pm 0.90$ \\
\hline 50 & $4.18 \pm 1.44$ & $0.76 \pm 0.28$ & $4.13 \pm 2.22$ & $4.53 \pm 3.40$ \\
\hline \multicolumn{5}{|l|}{ Light treatment (SL) } \\
\hline Natural light & $4.15 \pm 1.50$ & $0.64 \pm 0.15$ & $3.93 \pm 0.99$ & $1.87 \pm 1.45$ \\
\hline $\mathrm{R}+\mathrm{B}+\mathrm{FR}$ & $3.44 \pm 0.50$ & $0.68 \pm 0.19$ & $3.06 \pm 1.18$ & $4.02 \pm 1.57$ \\
\hline $\mathrm{R}+\mathrm{B}$ & $3.71 \pm 1.18$ & $0.55 \pm 0.16$ & $3.59 \pm 2.88$ & $4.85 \pm 3.83$ \\
\hline \multicolumn{5}{|l|}{ Significance ${ }^{(1)}$} \\
\hline DAT & ns & $*$ & ns & ns \\
\hline SL & ns & ns & ns & ns \\
\hline Control vs. LEDs & ns & ns & ns & ns \\
\hline $\mathrm{R}+\mathrm{B}$ vs. $\mathrm{R}+\mathrm{B}+\mathrm{FR}$ & ns & ns & ns & ns \\
\hline $\mathrm{DAT} \times \mathrm{SL}$ & ns & ns & ns & ns \\
\hline
\end{tabular}

(1) Significance: $\mathrm{ns}=$ not significant; ${ }^{*}$ for $p \leq 0.05$.

\subsection{Biochemical Characterization of the Endosperm of 'Carosello leccese' Fruits Grown under Natural Light}

The total polyphenols content of endosperm was more than 1.5 times higher than the external fruit tissue and tocopherols content did not vary among fruit tissues (Table 6). Furthermore, the total chlorophyll content was almost four times higher for the external tissues compared to the endosperm (Table 6) and the total carotenoids content was almost 2.4 times higher in exocarp + mesocarp tissues than in endosperm tissue (Table 6).

Table 6. Total polyphenols, tocopherols, carotenoids and chlorophylls contents of the exocarp, mesocarp and endosperm of 'Carosello leccese' fruits harvested on 50 DAT under "Natural light" conditions. Values are an average \pm SD of three replications.

\begin{tabular}{lcccc}
\hline & Polyphenols & Tocopherols & Carotenoids & Chlorophylls \\
\hline Fruit part & \multicolumn{4}{c}{$\mu \mathrm{g} \cdot \mathrm{g}^{-1}$ fresh weight } \\
\hline Exocarp + Mesocarp & $1.93 \pm 0.15$ & $0.64 \pm 0.27$ & $6.03 \pm 0.81$ & $7.50 \pm 0.99$ \\
Endosperm $^{(1)}$ & $5.05 \pm 1.19$ & $0.95 \pm 0.25$ & $1.78 \pm 2.79$ & $1.52 \pm 3.83$ \\
Significance $^{*}$ & $*$ & $\mathrm{~ns}$ & $* *$ & $*$ \\
\hline
\end{tabular}

(1) Significance: $\mathrm{ns}=$ not significant; ${ }^{*}$ and ${ }^{* *}$ significant for $p \leq 0.05$ and $p \leq 0.01$, respectively.

\section{Discussion}

\subsection{Supplementary Light Management and Its Effects on 'Carosello leccese' Yield and Fruit Quality}

After the introduction of LED technology as a supplementary light (SL) system for protected agriculture, the interest towards its application in Mediterranean greenhouses has increased in order to improve horticultural production during the fall-winter season. A recent study conducted by Palmitessa et al. [31,32] shows the positive effects of LED application on tomato fruit production and antioxidant content during an all-year round cycle conducted in a commercial semi-closed greenhouse located in Southern Italy. Similarly, Paucek et al. [33] demonstrated that LED SL application improves the precocity of tomato production in Mediterranean basins and Voutsinos et Al. [34] showed that lettuce is successfully grown in Greece under SL. Another crop cultivated under SL is the cucumber $[35,36]$ largely consumed in Northern Europe. Similar to the cucumber, there are other Cucurbitaceae species that are becoming more interesting to North European consumers: 'Carosello' and 'Barattiere', which are consumed as vegetables at the immature stage, such as cucumbers [21]. These species are cultivated in Southern Italy during the spring-summer period in open field or greenhouse conditions but, due to the high temperature and radia- 
tion needed, the crop cycle is interrupted during the fall-winter period [8]. To extend the cultivation period of 'carosello', during this study a local variety called 'Carosello leccese' was grown with LED interlight during a fall cycle (Figure 3). As shown in the results section, the plants grown with LEDs received a total DLI (DLI NL + DLI SL) of $16 \mathrm{~mol} \cdot \mathrm{m}^{-2} \cdot \mathrm{d}^{-1}$, while the plants grown only with $\mathrm{NL}$ received $7.33 \mathrm{~mol} \cdot \mathrm{m}^{-2} \cdot \mathrm{d}^{-1}$ (Figure 3 ). This means that the 'Carosello leccese' plants grown with LEDs received 1.2 times more radiation than NL conditions (Figure 3). In detail, Palmitessa et al. [22] reported that for cucumbers the optimal DLI range varied from 8 to $23 \mathrm{~mol} \cdot \mathrm{m}^{-2} \cdot \mathrm{d}^{-1} \mathrm{but}$, equaling the light requirement of 'Carosello leccese' with those of the cucumber, during this experiment the level of DLI NL fell below the optimal values around 40 DAT (Figure 3). In fact, as shown in Figure 4, if the production under different light treatments did not vary significantly until 40 DAT, after this period the 'Carosello leccese' plants grown under LEDs produced more than the plants grown only with NL (Figure 4). At the end of the crop cycle, the plants grown under LEDs obtained $27 \%$ higher yield than under NL conditions (Table 2), thanks to the higher number of fruits harvested under LEDs than under NL conditions (Table 2) and due to a higher water content, which is the usual consequence of a higher growth rate. It is likely that the high frequency of floral abortions phenomena (Figure 5) observed for the plants grown with NL reduced the number of fruits harvested in natural conditions. These results are comparable to those obtained by Palmitessa et al. [37] with tomatoes, according to which during a fall-winter cycle the tomato plants grown under LEDs obtained 25\% more yield and 20\% more fruits per plant than under control conditions. Moreover, during this study as well as in Palmitessa et al. [37], no difference of average fruit weight was found between light treatments, and the $\mathrm{R}+\mathrm{B}+\mathrm{FR}$ spectra did not add any other effects to those induced by $\mathrm{R}+\mathrm{B}$ spectra (Table 2 ). This last result is in line with the result of Zhen and Bugbee [38], which states that "far-red photons were equally efficient for photosynthesis when acting synergistically with the 400-700 nm photons". In this regard, further studies will be necessary to calculate the phytochrome photoequilibrium (PPE) of light modules used during this experiment as a metric for characterizing the influence of a specific light source on plant morphology and physiology [39]. Moreover, considering the plant density of 2.78 plants $\cdot \mathrm{m}^{-2}$, during this experiment the 'Carosello leccese' fruit yield under LEDs was around $10.7 \mathrm{~kg} \cdot \mathrm{m}^{-2}$ or $107 \mathrm{t} \cdot \mathrm{ha}^{-1}$, two tons less compared to the average production obtained by Parente et al. [18] during a spring-summer cycle. While considering the open field cultivation during summer time, the average yield of carosello was around $20 \mathrm{t} \cdot \mathrm{ha}^{-1}$ [40], more than 5 times lower compared with the yield obtained during this experiment.

With regard to the fruit dry weight (DW), the values found during this experiment (Table 2) are lower than those found by Parente et al. [18] (8.5-9.1 g.100 $\left.\mathrm{g}^{-1} \mathrm{FW}\right)$, but comparable with the values reported by Buttaro et al. [16] (4.7-4.9 $\left.\mathrm{g} \cdot 100 \mathrm{~g}^{-1} \mathrm{FW}\right)$. The difference in DW content could be explained by the different genotypes (landraces) considered and their different growth periods. In fact, as reported by Accogli et al. [41], there are 11 varieties of 'Meloncelle' belonging to C. melo L. subsp. melo conv. agrestis but with sub-variety not precisely determinable. Moreover, the average fruit weight during this study (219 g; Table 2) was similar to the average fruit weight obtained by Buttaro et al. [16] (201-205 g) and higher than the one obtained by Parente et al. [18] (120-129 g). Finally, fruit morphology was not influenced by SL treatments (Table 3) and it was comparable to the morphology of Indian melon (C. melo L. subsp. melo conv. agrestis called 'badi kachri'; [42]). Both 'Carosello leccese' and 'badi kachri' possess an elliptical-ovate shape, average fruit weight between 200 and $300 \mathrm{~g}$, fruit length between 100 and $150 \mathrm{~mm}$ and equatorial diameter between 60 and $90 \mathrm{~mm}$ (Table 3; [42]). As reported by Elia et al. [17] 'Carosello leccese' fruits were harvested when the placenta cavity was absent and it represented, on average, $25 \%$ of the total fruit weight. 


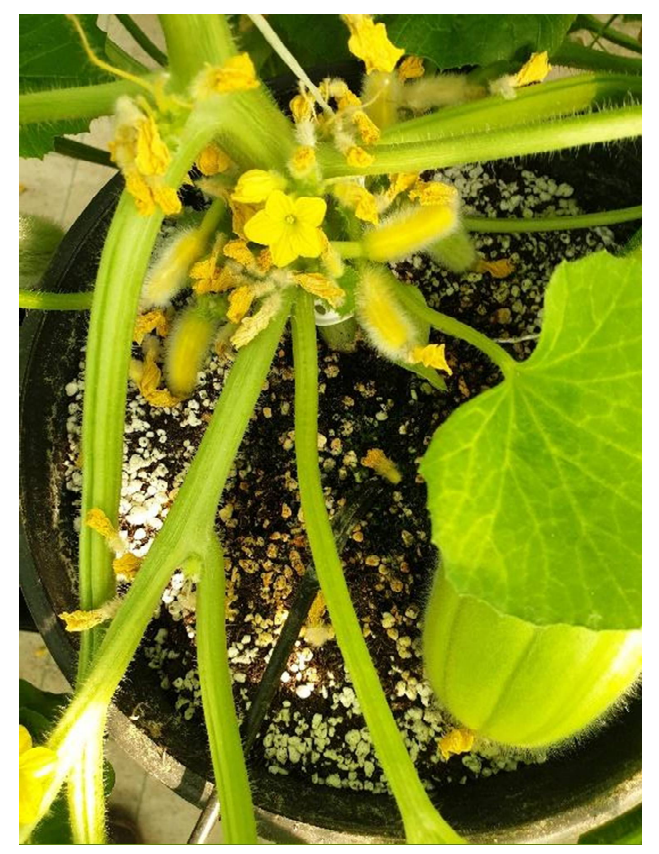

Figure 5. Hermaphrodite flowers abortion observed for 'Carosello leccese' plants (the photo was taken on 52 DAT).

\subsection{Color Traits and Nutritional Content of Different Fruit Parts}

The color of food surface is the first quality parameter evaluated by consumers and it carries a strong influence on a consumer's opinion about the food quality; in fact, color can be correlated with other quality attributes such as sensory, nutritional and visual or non-visual defects [43]. Supplemental light (SL) did not influence color parameters during this experiment, but great differences were detected between the external part (exocarp) and the internal part (mesocarp) of the fruits (Table 4). Starting from the luminosity $\left(\mathrm{L}^{*}\right)$ parameter, it was higher in the flesh than in the skin of 'Carosello leccese'. Nevertheless, L' of both was higher than that of 'Barattiere' (Table 4; [21]). Moreover, considering the $\mathrm{a}^{*}$ and $b^{*}$ parameters, the negative values of $a^{*}$ indicate a greenish color, while the positive values of $b^{*}$ indicate a yellowish one [25]. Generally, the skin (exocarp) of 'Carosello leccese' fruits was much "greener" ( $\left.a^{*}\right)$ and more "yellow" ( $\left.b^{*}\right)$ than the flesh (mesocarp), and the overall color intensity (hue and C) was higher for the skin than for the flesh (Table 4). These results confirm that the skin of 'unripe melons' could demonstrate primary (green) and secondary (yellow) colors, and that the expressions of these traits are modulated by different genes [44]. It is well known that chlorophyll is the main factor responsible for the green color, while yellow could be associated with the presence of carotenoids [45]. Generally, in melons, fruit development is associated with a decrease in chlorophyll content and an increase in carotenoids content [45] but, being harvested at immature stage, 'Carosello leccese' showed more chlorophyll content than carotenoids in exocarp and mesocarp tissues (Table 6). Instead, in the endosperm tissue the ratio between total chlorophylls and total carotenoids was around 1:1 (Table 6): it has been confirmed that the "green caviar" is a part of the 'Carosello leccese' fruits that must be valorized in order to reduce food waste generation due to its nutritional content. Furthermore, the variation of the content of the bioactive substance for the whole fruits was not influenced by SL treatments (Table 5), probably because the amount of SL supplied did not influence the secondary metabolism of the plants. The valorization of melon by-products is a critical step in food waste management to solve environmental problems [46]. If we consider that the placenta tissue (endosperm) of 'Carosello leccese', or in general of landraces of immature melons, is wasted, its valorization could be a key factor to improve the cultivation of these genotypes. Moreover, considering the total polyphenols content that provides health benefits, in particular by supporting the cardiovascular system [47], the placenta holds the highest content (Table 6). Finally, 
tocopherols are only produced by photosynthetic organisms; they are essential nutrients for humans, because they can efficiently quench singlet oxygen and scavenge various radicals, especially lipid peroxy radicals derived from polyunsaturated fatty acids, thereby terminating lipid peroxidation chain reactions [48]. Tocopherols, especially $\alpha$-tocopherols, are abundant in the oil extracted from melon seeds [49]. In fact, Maeda et al. [48] found that the seeds of land plants accumulate tocopherols at the highest levels of any plant tissue, suggesting that these compounds have an evolutionarily conserved function in the seeds. Furthermore, during this study, the content of tocopherols in 'Carosello leccese' was equal (or higher) in the placenta than the rest of the fruits (Table 5), confirming once again that the placenta or endosperm needs to be valorized as a functional food for human diet, thus reducing food waste production.

\section{Conclusions}

During this study we demonstrated that 'Carosello leccese' (local variety of Cucumis melo L.) could be valorized by increasing the cultivation period, which, in Southern Italy, is generally limited to the spring-summer period. With the application of LEDs as supplemental light technology, we demonstrated that the cultivation of 'Carosello leccese' during the fall season is possible, obtaining a yield comparable to that obtained in the summer. Moreover, the morphology, aspect (color) and the bioactive substances content of 'Carosello leccese' fruits are not negatively affected by LED application and the overall quality of the fruits could be a key factor in increasing the cultivation of this local variety. In particular, in this study we highlighted the need to reduce food waste and to increase the functional food in human diet, and that the valorization of the endosperm of 'Carosello leccese', which is generally thrown away, could represent an important step in this direction.

Author Contributions: Conceptualization, O.D.P., M.R., F.S. and P.S.; methodology, O.D.P., M.R., M.D., F.S. and P.S.; validation, M.D., F.S. and P.S.; formal analysis, M.D., F.S. and P.S.; investigation, O.D.P., A.S. and M.R.; resources, F.M., F.S. and P.S.; data curation, F.S., M.D. and P.S.; writing-original draft preparation, O.D.P.; writing-review and editing, F.S., M.D. and P.S.; visualization, O.D.P., B.L. and A.S.; supervision, F.S. and P.S.; project administration, F.M., F.S. and P.S.; funding acquisition, F.M., F.S. and P.S. All authors have read and agreed to the published version of the manuscript.

Funding: This research was funded by the Rural Development Programme of the Apulia Region (Italy) 2014-2020, Submeasure 16.2 (Support for pilot projects and the development of new products, practices, processes and technologies, and the transfer and the dissemination of the results obtained by the Operational Groups), in the framework of the SOILLESS GO project, project code (CUP) B97H20000990009. Paper n. 10.

Institutional Review Board Statement: Not applicable.

Informed Consent Statement: Not applicable.

Data Availability Statement: The raw data supporting the conclusions of this article will be made available by the authors, without undue reservation.

Acknowledgments: This paper has been awarded (ex-aequo) as the Best Paper Awards presented by a PhD student or a recently graduated PhD fellow, at the XIII Italian National Congress on Biodiversity “Biodiversità 2021", 7-9 September 2021, Foggia (Italy).

Conflicts of Interest: The authors declare no conflict of interest.

\section{References}

1. Bisognin, D.A. Origin and evolution of cultivated cucurbits. Ciência Rural 2002, 32, 715-723. [CrossRef]

2. Di Gioia, F.; Renna, M.; Santamaria, P. Sprouts, Microgreens and “Baby Leaf" Vegetables. In Minimally Processed Refrigerated Fruits and Vegetables; Springer: Boston, MA, USA, 2017; pp. 403-432, ISBN 978-1-4939-7016-2.

3. Renna, M.; Di Gioia, F.; Leoni, B.; Mininni, C.; Santamaria, P. Culinary Assessment of Self-Produced Microgreens as Basic Ingredients in Sweet and Savory Dishes. J. Culin. Sci. Technol. 2017, 15, 126-142. [CrossRef]

4. Sotelo, A.; López-García, S.; Basurto-Peña, F. Content of nutrient and antinutrient in edible flowers of wild plants in Mexico. Plant Foods Hum. Nutr. 2007, 62, 133-138. [CrossRef] 
5. Lestari, B.; Meiyanto, E. A Review: The Emerging Nutraceutical Potential of Pumpkin Seeds. Indones. J. Cancer Chemoprev. 2018, 9, 92. [CrossRef]

6. Patel, S.; Rauf, A. Edible seeds from Cucurbitaceae family as potential functional foods: Immense promises, few concerns. Biomed. Pharmacother. 2017, 91, 330-337. [CrossRef]

7. Chunduri, J.R. Antoxidant and Nutritional Analysis of Edible Cucurbitaceae Vegetables of India. Int. J. Bioassays 2013, 2, 1124-1129.

8. Conversa, G.; Gonnella, M.; Santamaria, P.; Vincenzo, V. Caratterizzazione e valorizzazione di due tipici ortaggi pugliesi: Carosello e barattiere. Colt. Protette 2005, 34, 4-13.

9. Pavan, S.; Marcotrigiano, A.R.; Ciani, E.; Mazzeo, R.; Zonno, V.; Ruggieri, V.; Lotti, C.; Ricciardi, L. Genotyping-by-sequencing of a melon (Cucumis melo L.) germplasm collection from a secondary center of diversity highlights patterns of genetic variation and genomic features of different gene pools. BMC Genom. 2017, 18, 59. [CrossRef] [PubMed]

10. Renna, M.; Montesano, F.F.; Signore, A.; Gonnella, M.; Santamaria, P. Biodiverso: A case study of integrated project to preserve the biodiversity of vegetable crops in puglia (southern Italy). Agriculture 2018, 8, 128. [CrossRef]

11. Perrino, P.; Hammer, K.; Hanelt, P. Carosello and the taxonomy of Cucumis melo L., especially of its vegetables races. Acta Hortic. 1986, 34, 95-100. [CrossRef]

12. Hammer, K.; Hanelt, P.; Perrino, P. Carosello and the taxonomy of Cucumis melo L. especially of its vegetable races. Genet. Resour. Crop. Evol. 1986, 34, 249-259. [CrossRef]

13. Paris, H.S.; Daunay, M.C.; Janick, J. Medieval iconography of watermelons in Mediterranean Europe. Ann. Bot. 2013, 112, 867-879. [CrossRef] [PubMed]

14. Laghetti, G.; Accogli, R.; Hammer, K. Different cucumber melon (Cucumis melo L.) races cultivated in Salento (Italy). Genet. Resour. Crop Evol. 2008, 55, 619-623. [CrossRef]

15. Macchia, F.; Pacucci, G. Sul numero cromosomico del cucumis coltivato nelle puglie con il nome di «carosello». Caryologia 1961, 14, 151-153. [CrossRef]

16. Buttaro, D.; Bonasia, A.; Minuto, A.; Serio, F.; Santamaria, P. Effect of silicon in the nutrient solution on the incidence of powdery mildew and quality traits in carosello and barattiere (Cucumismelo L.) grown in a soilless system. J. Hortic. Sci. Biotechnol. 2009, 84, 300-304. [CrossRef]

17. Elia, A.; Santamaria, P. Biodiversity in vegetable crops: A heritage to save. The case of the Puglia region. Ital. J. Agron. 2013, 8, 21-34. [CrossRef]

18. Parente, A.; Buttaro, D.; Conversa, G.; Serio, F.; Santamaria, P. Confronto tra sistemi di coltivazione di carosello e barattiere in serra II. Aspetti qualitativi. Colt. Protette 2005, 34, 28-35.

19. Jing, S.; Zou, H.; Wu, Z.; Ren, L.; Zhang, T.; Zhang, J.; Wei, Z. Cucurbitacins: Bioactivities and synergistic e ff ect with small-molecule drugs. J. Funct. Foods 2020, 72, 1-9. [CrossRef]

20. Vergauwen, D.; De Smet, I. Watermelons versus Melons: A Matter of Taste. Trends Plant Sci. 2019, 24, 973-976. [CrossRef]

21. Renna, M.; D'Imperio, M.; Gonnella, M.; Parente, A.; Santamaria, P.; Serio, F. Barattiere: An italian local variety of Cucumis melo L. with quality traits between melon and cucumber. Plants 2020, 9, 578. [CrossRef] [PubMed]

22. Palmitessa, O.D.; Pantaleo, M.A.; Santamaria, P. Applications and Development of LEDs as Supplementary Lighting for Tomato at Different Latitudes. Agronomy 2021, 11, 835. [CrossRef]

23. Palmitessa, O.D.; Leoni, B.; Montesano, F.F.; Serio, F.; Signore, A.; Santamaria, P. Supplemental lighting with LED for efficient year- round production of soilless tomato in a Mediterranean greenhouse. Acta Hortic. 2021, 367-374. [CrossRef]

24. Hoagland, D.R.; Arnon, D.I. The water-culture method for growing plants without soil. Circ. Calif. Agric. Exp. Stn. 1950, $347,32$.

25. Renna, M.; Pace, B.; Cefola, M.; Santamaria, P.; Serio, F.; Gonnella, M. Comparison of two jam making methods to preserve the quality of colored carrots. LWT-Food Sci. Technol. 2013, 53, 547-554. [CrossRef]

26. Abu-Reidah, I.M.; Arráez-Román, D.; Quirantes-Piné, R.; Fernández-Arroyo, S.; Segura-Carretero, A.; Fernández-Gutiérrez, A. HPLC-ESI-Q-TOF-MS for a comprehensive characterization of bioactive phenolic compounds in cucumber whole fruit extract. Food Res. Int. 2012, 46, 108-117. [CrossRef]

27. Laddomada, B.; Durante, M.; Mangini, G.; D’Amico, L.; Lenucci, M.S.; Simeone, R.; Piarulli, L.; Mita, G.; Blanco, A. Genetic variation for phenolic acids concentration and composition in a tetraploid wheat (Triticum turgidum L.) collection. Genet. Resour. Crop Evol. 2017, 64, 587-597. [CrossRef]

28. Sadler, G.; Davis, J.; Dezman, D. Rapid Extraction of Lycopene and P-Carotene from Reconstituted Tomato Paste and Pink Grapefruit Homogenates. J. Food Sci. 1990, 55, 1460-1461. [CrossRef]

29. Perkins-veazie, P.; Collins, J.K.; Pair, S.D.; Roberts, W. Lycopene content differs among red-fleshed watermelon cultivars. J. Sci. Food Agric. 2001, 987, 983-987. [CrossRef]

30. Durante, M.; Salvatore, M.; Paolo, P.; Rizzi, V.; Caroli, M.; De Piro, G.; Fini, P.; Luigi, G.; Mita, G. $\alpha$-Cyclodextrin encapsulation of supercritical $\mathrm{CO}_{2}$ extracted oleoresins from different plant matrices: A stability study. Food Chem. 2016, 199, 684-693. [CrossRef]

31. Palmitessa, O.D.; Paciello, P.; Santamaria, P. Supplemental LED Increases Tomato Yield in mediterranean Semi-Closed Greenhouse. Agronomy 2020, 10, 1353. [CrossRef]

32. Palmitessa, O.D.; Durante, M.; Caretto, S.; Milano, F.; D'imperio, M.; Serio, F.; Santamaria, P. Supplementary light differently influences physico-chemical parameters and antioxidant compounds of tomato fruits hybrids. Antioxidants 2021, $10,687$. [CrossRef] 
33. Paucek, I.; Pennisi, G.; Pistillo, A.; Appolloni, E.; Crepaldi, A.; Calegari, B.; Spinelli, F.; Cellini, A.; Gabarrell, X.; Orsini, F.; et al. Supplementary LED Interlighting Improves Yield and Precocity of Greenhouse Tomatoes in the Mediterranean. Agronomy 2020, 10, 1002. [CrossRef]

34. Voutsinos, O.; Mastoraki, M.; Ntatsi, G.; Liakopoulos, G.; Savvas, D. Comparative Assessment of Hydroponic Lettuce Production Either under Artificial Lighting, or in a Mediterranean Greenhouse during Wintertime. Agriculture 2021, 11, 503. [CrossRef]

35. Garcia, C.; Lopez, R.G. Supplemental Radiation Quality Influences Cucumber, Tomato, and Pepper Transplant Growth and Development. HortScience 2020, 55, 804-811. [CrossRef]

36. Särkkä, L.E.; Jokinen, K.; Ottosen, C.O.; Kaukoranta, T. Effects of HPS and LED lighting on cucumber leaf photosynthesis, light quality penetration and temperature in the canopy, plant morphology and yield. Agric. Food Sci. 2017, 26, 101-109. [CrossRef]

37. Palmitessa, O.D.; Leoni, B.; Montesano, F.F.; Serio, F.; Signore, A.; Santamaria, P. Supplementary Far-Red Light Did Not Affect Tomato Plant Growth or Yield under Mediterranean Greenhouse Conditions. Agronomy 2020, 10, 1849. [CrossRef]

38. Zhen, S.; Bugbee, B. Substituting Far-Red for Traditionally Defined Photosynthetic Photons Results in Equal Canopy Quantum Yield for $\mathrm{CO}_{2}$ Fixation and Increased Photon Capture During Long-Term Studies: Implications for Re-Defining PAR. Front. Plant Sci. 2020, 11, 1-14. [CrossRef]

39. Sager, J.C.; Smith, W.O.; Edwards, J.L.; Cyr, K.L. Photosynthetic Efficiency and Phytochrome Photoequilibria Determination Using Spectral Data. Am. Soc. Agric. Eng. 1988, 31, 1882-1889. [CrossRef]

40. Cantore, V.; Boari, F.; Bianco, V.V.; Pertosa, N. Effetti della salinità su carosello e barattiere (Cucumis melo L.). Colt. Protette 2005, 5, $37-43$.

41. Accogli, R.; Nicolì, F.; De Bellis, L. Tradizioni e saperi attorno ad alcune varietà locali di Cucumis melo L. in Salento (Puglia). Thalassia Salentina 2014, 36, 43-52. [CrossRef]

42. Pandey, A.; Ranjan, P.; Ahlawat, S.P.; Bhardwaj, R.; Dhariwal, O.P.; Singh, P.K.; Malav, P.K.; Harish, G.D.; Prabhu, P.; Agrawal, A. Studies on fruit morphology, nutritional and floral diversity in less-known melons (Cucumis melo L.) of India. Genet. Resour. Crop Evol. 2021, 68, 1453-1470. [CrossRef]

43. Pathare, P.B.; Opara, U.L.; Al-Said, F.A.J. Colour Measurement and Analysis in Fresh and Processed Foods: A Review. Food Bioprocess Technol. 2013, 6, 36-60. [CrossRef]

44. Pitrat, M. Phenotypic diversity in wild and cultivated melons (Cucumis melo). Plant Biotechnol. 2013, 30, 273-278. [CrossRef]

45. Reid, M.S.; Lee, T.H.; Pratt, H.K.; Chichester, C.O. Chlorophyll Carotenoid Changes Muskmelon. J. Am. Soc. Hortic. Sci. 1970, 95, 814-815.

46. Gómez-García, R.; Campos, D.A.; Aguilar, C.N.; Madureira, A.R.; Pintado, M. Valorization of melon fruit (Cucumis melo L.) by-products: Phytochemical and Biofunctional properties with Emphasis on Recent Trends and Advances. Trends Food Sci. Technol. 2020, 99, 507-519. [CrossRef]

47. Rodríguez-Pérez, C.; Quirantes-Piné, R.; Fernández-Gutiérrez, A.; Segura-Carretero, A. Comparative characterization of phenolic and other polar compounds in Spanish melon cultivars by using high-performance liquid chromatography coupled to electrospray ionization quadrupole-time of flight mass spectrometry. Food Res. Int. 2013, 54, 1519-1527. [CrossRef]

48. Maeda, H.; DellaPenna, D. Tocopherol functions in photosynthetic organisms. Curr. Opin. Plant Biol. 2007, 10, 260-265. [CrossRef]

49. Silva, M.A.; Albuquerque, T.G.; Alves, R.C.; Oliveira, M.B.P.P.; Costa, H.S. Melon (Cucumis melo L.) by-products: Potential food ingredients for novel functional foods? Trends Food Sci. Technol. 2020, 98, 181-189. [CrossRef] 